\title{
Grazing steer performance in pure stands of dwarf elephant grass or mixed with Arachis pintoi
}

\author{
Steben Crestani ${ }^{1}$, Henrique Mendonça Nunes Ribeiro Filho ${ }^{1 \dagger}$, Marcolino Frederico Miguel $^{1}$, \\ Cristiano de Oliveira Ramos ${ }^{1}$ and Edison Xavier de Almeida ${ }^{2}$
}

${ }^{1}$ UDESC, SC, Brazil; ${ }^{2}$ EPAGRI, SC, Brazil

\section{Introduction}

The introduction of legumes in grass-based swards provides some economic and agronomic advantages, often producing an increase in performance of grazing ruminants. In this context, Arachis pintoi is a species that has a high nutritional value compared with the most of the tropical legumes (Lascano, 1994). The aim of this work was to assess grazing steer performance in pure stands of dwarf elephant grass (Pennisetum purpureum cv. Mott) with nitrogen (N) fertilization or mixed with Arachis pintoi without $\mathrm{N}$ fertilization.

\section{Material and methods}

The experiment was conducted at Epagri Experimental Station near to Ituporanga (Santa Catarina, Brazil), from January to March 2010. A 14 ha experimental unit, one half established with Pennisetum purpureum (PG) and the other half as a mixed sward of Pennisetum purpureum cv.Mott/Arachis pintoi (PAG), was used. Pasture was divided into 32 paddocks, 16 foe each sward type. Twelve Charolês $\times$ Devon breed steers, aged up to 16 months with initial live weights of $288 \pm 15 \mathrm{~kg}$ were divided in four uniform groups (two per treatment) according to body weight. The pastures were managed under rotational grazing with an herbage allowance of $6 \mathrm{~kg}$ of grass leaf dry matter (DM) per steer per day irrespective of the treatment. The grazing time for each paddock was calculated from the herbage mass estimated daily by a visual method (Haydock and Shaw, 1975). The sward height was measured daily with a sward stick and the morphological composition of the swards for each treatment and the proportion of Arachis pintoi in the PA swards were determined on two paddocks by grazing cycles, before and after grazing. Each constituent was dried in an oven for $48 \mathrm{~h}$ at $60^{\circ} \mathrm{C}$ to determine morphological composition on a DM basis. Steers were weighted at beginning and at the end of each grazing cycle in order to estimate the average daily gain (ADG). The data were submitted to the variance analysis using as factors the grazing cycle and the pasture type within each cycle.

\section{Results}

Average daily gain was around $1.0 \mathrm{~kg}$ in both studied pastures (Table 1). Pre- and post-grazing sward height did not change $(P>0.10)$ with the introduction of the Arachis pintoi in comparison with the pure dwarf elephant grass. Sward surface height decreased around $35 \%$ of pregrazing height and the proportion of Arachis pintoi was $25 \%$ of green DM on pre-grazing and $40 \%$ of green DM on post-grazing. These results showed that the animals mainly eat the upper stratum of the pasture, composed basically of live lamina of elephant dwarf grass. Therefore within the grazing management regime the legume featured as a low proportion of the diet.

Table 1 Effects of sward type on sward height and animal performance

\begin{tabular}{|c|c|c|c|c|c|c|c|}
\hline \multirow[b]{2}{*}{ Parameters } & \multicolumn{2}{|c|}{ 1st cycle } & \multicolumn{2}{|c|}{ 2nd cycle } & \multirow[b]{2}{*}{ s.e.d. } & \multicolumn{2}{|c|}{ Effects } \\
\hline & PG & PAG & PG & PAG & & Sward & Cycle \\
\hline Pre-grazing sward height $(\mathrm{cm})$ & 94.2 & 87.3 & 91.2 & 84.2 & 4.50 & NS & NS \\
\hline Post-grazing sward height $(\mathrm{cm})$ & 61.2 & 61.2 & 56.0 & 56.0 & 3.68 & NS & NS \\
\hline Average daily gain $(\mathrm{kg})$ & 0.80 & 0.97 & 1.05 & 0.99 & 0.195 & NS & NS \\
\hline
\end{tabular}

\section{Conclusions}

The presence of the Arachis pintoi in pastures of elephant grass is insufficient to improve the animal performance when the intensity of grazing does not exceed $35 \%$ of the pre-grazing sward height. The effect of the introduction of this legume in situations of higher grazing intensity or offering the Arachis pintoi in strips adjacent to mixed swards should be studied.

\section{References}

Haydock KP and Shaw NH 1975. Austr. J. Exp. Agric. Anim. Husb. 15, 663-670.

Lascano CE 1994. Biology and Agronomy of forages Arachis. P.109-121.

\footnotetext{
${ }^{\dagger}$ E-mail: a2hrf@cav.udesc.br
} 